\title{
Entrepreneurship and institutional change in Post-socialist rural areas: Some evidence from Russia and the Ukraine*
}

\author{
Christos Kalantaridis, Lois Labrianidis, Ivaylo Vassilev ${ }^{* *}$
}

Are entrepreneurs in rural areas of Russia and the Ukraine any different from their urban based counterparts? What are the implications of the distinctiveness of rural entrepreneurship upon the institutional setting - given the weakness of the State? We focus upon the experience of rural areas of Novosibirsk and the Republic of Bashkortostan in Russia and Transcarpathia in the Ukraine. We argue that whilst in urban settings the advancement of post-socialist transformation resulted in increased diversity in the type of individual engaged in entrepreneurship. This raises concerns about the pace and direction of change in rural areas. However, even within the three localities under investigation there appears to be a growing divergence in the pathways of change.

Unterscheiden sich Unternehmer in ländlichen Gebieten Russlands und der Ukraine von ihren städtischen Kollegen? Was sind die Folgen der Besonderheit von ländlichem Unternehmertum auf die institutionellen Rahmenbedingungen vor dem Hintergrund des schwachen Staates? Dabei konzentrieren wir uns auf die ländlichen Gebiete von Nowosibirsk und der Republik Baschkortostan in Russland sowie Transkarpatien in der Ukraine. Wir behaupten, dass der Fortschritt der postsozialistischen Transformation lediglich im städtischen Umfeld zu einer verstärkten Vielfalt von individuellem Engagement im Unternehmertum geführt hat, nicht aber auf dem Lande. Dies verweist auf die Problematik des Tempos und der Richtung der Veränderungen in ländlichen Gebieten. Allerdings bestehen auch zwischen den drei Regionen wachsende Unterschiede bezüglich der eingeschlagenen Wandlungspfade.

Key words: entrepreneurs; institutions; rural areas; post-socialist transformation

\footnotetext{
Manuscript received: 02.30.06, accepted: 25.09.06 (1 revision)

** Christos, Kalantaridis, Professor, University of Teesside. Main research areas: Institutional change, rural entrepreneursip and globalisation strategy. Corresponding address: c.kalantaridis@tees.ac.uk

Lois, Labrianidis, Professor, University of Macedonia. Main research areas: Industrial location and economic consequences of immigration.

Ivaylo, Vassilev, Research Fellow, University of Northampton. Main Research areas: Business strategy, globalization and transformations of Eastern Europe.
} 


\section{Introduction}

The realisation of reforms and the working of market institutions in postsocialist rural areas rests heavily upon the emergence of entrepreneurial individuals. However, the emergence of such persons is conditioned by the defining characteristics of the processes of post-socialist transformation and rurality. On the supply side, the absence of positive role models in the family and the society, the inability to accumulate capital and the skills necessary to engage in the process of business enterprise, and a historical hostility towards private business - that in large parts of Russia and the Ukraine pre-dates Socialism - underline the magnitude of the task of generating entrepreneurs (Rehn/Talaas 2004). Moreover, even in Soviet Union, where the internal registration system restricted migration from villages to the town, there was widespread rural-urban migration. Up to 100 million migrants moved from the countryside to the main towns and cities during the post-war Soviet era (Barkhatova et al. 2001). On the demand side, the manifestations of postsocialist transformation in the countryside combined with diverse resource (such as the quantity of labour, the availability of land and capital, the size of local markets) endowments between urban and rural areas impact upon the quantity and quality of entrepreneurial opportunities available. However, to date there has been precious little research exploring rural entrepreneurship in Russia and the Ukraine. This relative neglect indicates that rural areas constitute political and economic periphery and are of secondary importance in the post-soviet space (Johnson et al. 2000).

One plausible explanation for the neglect of rural entrepreneurship is that rurality 'does not matter at the early stages of reform'. This means that the main constraints in the emergence of entrepreneurs emanate from the magnitude of institutional change and the volatility of the macro-economic setting that are defining post-soviet space as a whole. As a consequence, the influence of the rural is often perceived to be of secondary importance. There is some evidence to support this argument (Johnson et al. 2000). However, as the process of reform advances at a different pace between as well as within countries, the characteristics of the rural become more salient. More specifically, the relatively slow pace of reform (in the national context) in agriculture, a significant source of rural employment and income generation, and the ambivalence of policy towards formerly state and collective agricultural enterprises influence significantly the transformation of the countryside (Wegren 2004). Moreover, in Russia and the Ukraine the impact of geographical remoteness, characteristic of the rural, extends beyond factor and product markets to social considerations. In addition to their marginality rural areas are also characterised by strong communal relations (typical of traditional regimes, but reinforced during socialism). These may act as a restraint on aggressive accumulation through moral and ethical pressure on the part of the community, and may also 
discourage the growth of inequality between community members. Thus, individuals who aspire to engage in entrepreneurial pursuits are often confronted with local resistance - by the population at large as well as by the directors of formerly state and collective ventures who tend to control access to economic opportunities (Allina-Pisano 2004). As a result, urban and rural areas follow dissimilar paths of economic and social restructuring. In as much as entrepreneurial activities are concerned, cities are rapidly developing a diverse set of domestic entrepreneurs and are successful in attracting international capital. In contrast, entrepreneurs in rural areas are both less numerous and diverse, and are more closely attached to traditional norms and behaviours (that are also linked with the old institutional setting).

Within this context we aspire to make a positive contribution in the literature by focusing upon rural entrepreneur. We set out to explore the characteristics of entrepreneurship and their implications upon the process of institutional change in post-socialist regimes. The emphasis attached here to the role of entrepreneurs in the process of institutional change is the result of two recent advances in knowledge. The first concerns with the realisation of the limitations of State driven (top-down) reform. Research from a number of quarters lends support to this view. Within the increasingly prominent new institutionalist tradition there is a growing acceptance that private property rights and their enforcement in post-socialist regimes are 'sub-optimal' (Mcmillan/Woodruff 2002; Kuznetsov/Kuznetsova 2003). Those originating from a sociological perspective argue that state powers are both peremptory and poorly defined offering scope for manoeuvre to local officials (Obolonski 1997; Barkhatova et al. 2001). This view is also shared from those examining agrarian reform in the Russian and Ukrainian countryside (Allina-Pisano 2004; Wegren 2004). Indeed, the slow pace of agrarian reform combined with increased difficulty of enforcement may actually further reduce the ability of the state to drive change in relatively distant, and economically less important, rural areas. The second concerns with the acknowledgement that the process of institutional change goes beyond the mere clarity and enforceability of formal institutions in general and private property rights in particular. Other institutions such as the political structure, the family, networks of friends, habits and beliefs (for example in relation to corruption) need to be taken into account. These advances in knowledge prompt a shift in emphasis to the role of other economic agents - including entrepreneurs - in the process of institutional (formal and informal) change. In addressing these issues, we draw upon the results of extensive fieldwork investigation in rural areas from three diverse regions: Trascarpathia in Westernmost Ukraine, the Republic of Bashkortostan at the edge of European Russia, and the Novosibirsk region in Western Siberia (Figure 1).

The paper is organised as follows. Firstly, a conceptualisation of entrepreneurship is developed. We then go on to review the literature on urban 
post-socialist entrepreneurship in Russia and the Ukraine, in the absence of any published research on rural entrepreneurship. Section 4 introduces the methods employed. Subsequently, an outline of the study areas is presented, focusing upon the salient socio-economic features which help explain rural entrepreneurial attributes. Section 6 examines the characteristics of rural entrepreneurs, whilst the following Section identifies entrepreneurial groupings with distinct features. The penultimate Section explores how entrepreneurs may influence the pace and direction of institutional change. Finally, we offer some conclusions.

Figure 1. The case study areas in context

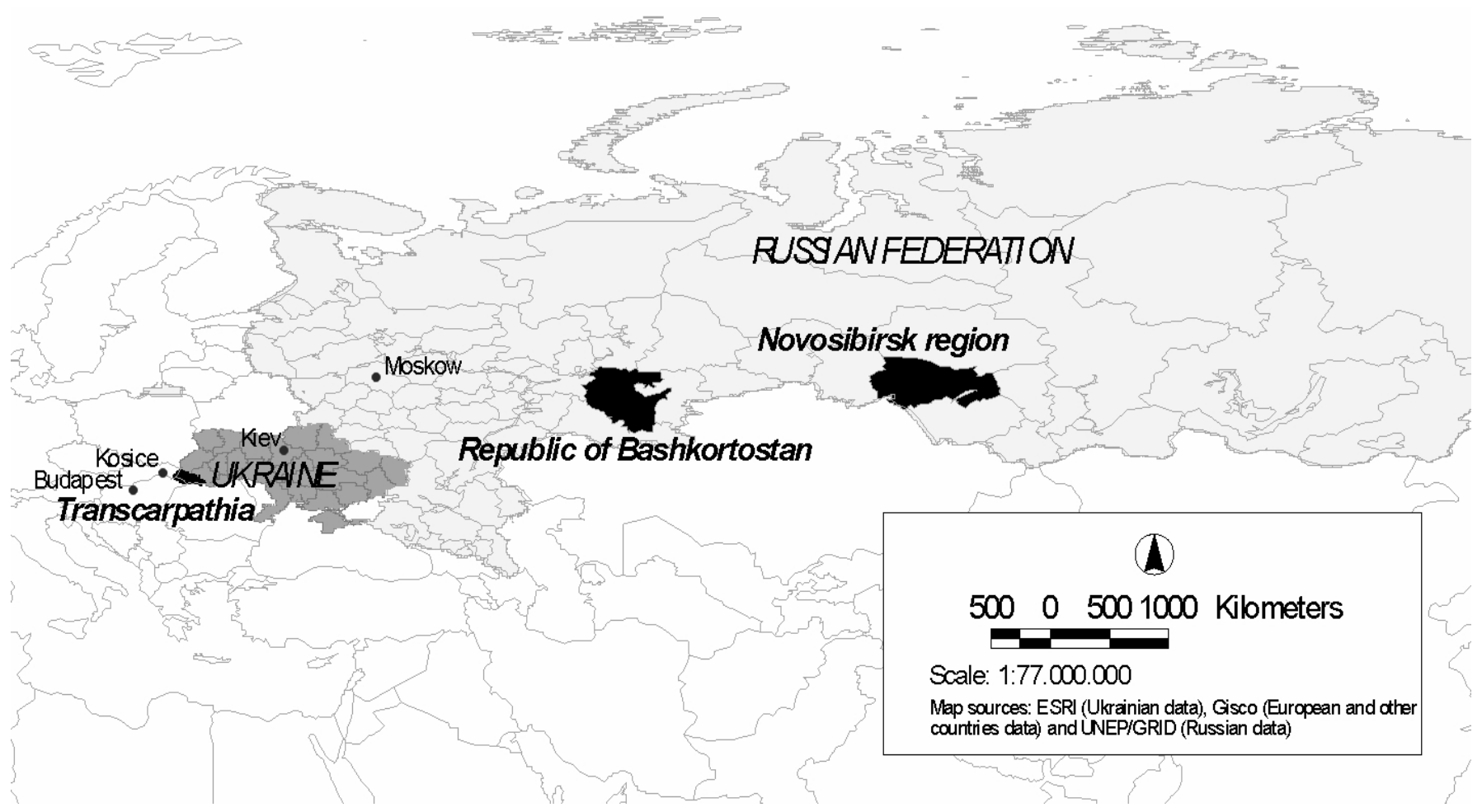

\section{Conceptualising entrepreneurship}

Defining entrepreneurship constitutes an essential condition in exploring the distinctiveness (or not) of rural entrepreneurs in Russia and the Ukraine. Despite the considerable growth in that body of literature exploring the function and attributes of the entrepreneur there is 'a profound lack of consistency of terminology and method' (Brazeal/Herbert 1999:29) in the field of entrepreneurial studies. There is a myriad of conceptualisations of the entrepreneur (Binks/Vale 1991; Martinelli 1994; Kalantaridis 2004). This diversity has significant effects upon the categorisation of individuals as 
entrepreneurs or not. On the one end of the spectrum there are broad definitions, such as that provided by Cantillon (1755), whereby the entrepreneur is an economic actor taking decisions under conditions of uncertainty. On the other end of the spectrum are very narrow definitions such as that provided by Schumpeter (1934), identifying entrepreneurship with the introduction of radical innovations. Divergence of opinion regarding the definition of entrepreneurship is also reflected on the growing body of literature examining entrepreneurship in post-socialist regimes.

Early studies (Ageev et al. 1995; Shulus 1996) adopt restrictive definitions, whilst more recent studies use broader definitions with the aim of researching entrepreneurship at the margins (Barkhatova et al. 2001; Rehn/Taalas 2004). However, it is Richard Scase $(1997 ; 2003)$ who explicitly addresses the question of what are the boundaries of entrepreneurship in post-socialist regimes. His point of departure is a distinction - that draws upon Weber's conceptual schema - between entrepreneurship and proprietorship. The former term refers to the pursuit of capital accumulation and business growth, often at the expense personal consumption. Proprietorship refers to 'ownership of property and other assets such that, can be but not necessarily, used for trading purposes and therefore to realise profits, are not utilised for the purpose of longer term process of capital accumulation' (Scase 1997:14).

We think of entrepreneurship as putting together factors of production, as well as contracts with other entrepreneurs and other economic actors in a network of production and distribution. Entrepreneurship, unlike management, involves the realisation, and, the ability to make judgemental decisions about the process in its entirety. Placed within the context of existing theoretical constructs, the definition used for the purposes of our investigation, follows on a lengthy tradition of broad conceptualisations of the entrepreneur. There are two key elements to our conceptualisation of entrepreneurship. The first concerns with the co-ordinating function of entrepreneurs, following along the lines of the tradition initiated by Say. However, our definition expands the notion of combination and co-ordination beyond factors of production, to include contracts and personal as well as inter-organisational relationships (and the embodied information and knowledge) as key assets in economic activity. The second key element of our conceptualisation of entrepreneurship concerns with the judgemental nature of entrepreneurial decision-making. This means that all combinations of factors of production and networks of relationships are developed at present but are oriented towards the future. This definition aims to be inclusive, capturing entrepreneurship in all its manifestations.

\section{Urban entrepreneurship in Russia and the Ukraine}

This Section sets out to review the accumulated literature on entrepreneurship in Russia and the Ukraine with the aim of tracing patterns of entrepreneurship in 
urban locales. In doing so, it draws upon findings of research published during the past decade. However, attempts at comparison between the urban-based literature and our rural study are hampered by the use of different sample criteria. Many previous studies concentrate upon entrepreneurs that are economically significant, in other words, individuals responsible for the creation of relatively large numbers of salaried/wage jobs (Ageev et al. 1995). As a consequence, marginal entrepreneurial ventures receive less attention. Some other researchers introduce other restrictive criteria, such as the age of the firm (Smallbone/Welter 2001) and the age of the entrepreneur (Roberts/Tholen 1998) that influence results. Another factor that may influence the results of empirical research in post-socialist entrepreneurship is time. More specifically, the fieldwork of research of previous published works was conducted between 1994 and 2000, a very diverse period in the context of Russia and the Ukraine, during which change in the external environment was both rapid and multi-directional. Thus, attempts to compare our findings emanating from rural locations with those of studies from different geographical settings will be cautious and will acknowledge the impact of diverse methodologies and time.

There is near universal agreement among researchers regarding the characteristics and motivation of entrepreneurs in Russia. Shulus, in a study of 500 Russian entrepreneurs, conducted in early 1994, argues that he is 'a man aged between 30 and 40 with a university degree' (Shulus 1996:105). He goes on to suggest that entrepreneurs in Russia are driven either by opportunism or more 'mainstream' business objectives. Drawing from a study of 32 successful Moscowite entrepreneurs Ageev et al. (1995) claim that 'the majority of the entrepreneurs (84\%) were male with an average age of 34.1 years ... [S]ixty-six percent had a college degree and the remainder the equivalent of a high school degree or some college' (Ageev et al. 1995:371-372). For Ageev et al. (1995), like Shulus, pull factors provide the main incentive behind the decision to start a business. Push factors, such as necessity are reported only by $16 \%$ of what is admittedly a small sample. More or less at the same time, Green et al. (1996) posit that $79 \%$ of 'new generation' entrepreneurs in Moscow are males, whilst their mean age is 30 years, and nearly $60 \%$ possess a higher education qualification (sample size $=108$ ). They go on to argue that internal locus for control and need for achievement are the main drives of entrepreneurs. In an influential study of Russian entrepreneurship, the OECD (1998) reports that most entrepreneurs are males aged between $36-45$ years old. This is despite the growing involvement of females and younger individuals in the process of business enterprise during the latter stages of reform. As far as educational attainment is concerned, $80 \%$ of Russian entrepreneurs hold university diplomas, whilst one in ten have doctoral degrees (OECD 1998). More recently Barkhatova et al. (2001) argue that entrepreneurs derive 'from the former Soviet middle class, the professionals, the highly skilled workers and military officers 
(who) have suffered most of all social groups as a result of the reforms' (opcit, 251).

A similar picture emerges from the handful of published studies of Ukrainian entrepreneurship to date. Roberts and Tholen (1998), in a study of 50 successful, urban entrepreneurs under the age of 30, conducted in 1996, claim that the respondents are overwhelmingly male ( $82 \%$ ), possess some form of higher education qualification, and have parents who held intelligentsia, managerial and professional jobs. This study suggests that young Ukrainian entrepreneurs, prior to completing their education, anticipated careers in state departments or enterprises, however, they were forced to set-up their own enterprises when state sector jobs disappeared or never materialised. More recently, Smallbone and Welter (2004), exploring entrepreneurship in predominantly urban areas of two regions (Kiev/Vinitsa), report that some $80 \%$ of the total are males, whilst most fall within the 36-45 years age group. Ukrainian entrepreneurs also appear to be better-educated individuals: some $85 \%$ possess some higher education qualifications. Pull factors, such as independence, the desire to increase personal and family incomes, and personal fulfilment, are by far the most important. Unemployment and disappointment with the previous job are reported by just over one in ten of the respondents - though this low incidence of push factors can be explained in part by the sample selection criteria (excluding enterprises less than one year old and most personal services).

While researchers agree on the personal characteristics and motivation that drives entrepreneurship, they identify somewhat different groupings of entrepreneurs - a disparity influenced in large part by temporal differences. Kuznetsova (1999) identifies three entrepreneurial clusters during the Breznev era. The first cluster comprised of unregistered individuals who provided services outside and inside the state sector, and included blue-collar workers, engineers, teachers, doctors etc. The second grouping - defined as shadow entrepreneurs - traded with state enterprises, and filled the gaps in distribution generated by the bottlenecks of the planning system. The third grouping comprised of directors of state enterprises that behaved entrepreneurially in an increasingly deficient and complex system. According to Kuznetsova (1999), during the early 1990s, those in the latter category were among the main beneficiaries of privatisation. Another grouping of entrepreneurs during the early stages of the reform comprised of state and regional party officials, who controlled the conversion of state into private property. More than half of them occupied decision-making positions either in the state or private sector. 'New wave' entrepreneurs made-up a third grouping. These were 'high-qualified, well-educated specialists who are bored to death with the system ... [T]he average age of this strata is 30-40, a lot of them has $\mathrm{PhD}$ degree ... non-standard intellect ... [and] is ready to take reasonable risk' (Kuznetsova 1999:6465).Shadow businessmen of all types formed the fourth cluster of Russian 
entrepreneurs. This typology is identical with the one advanced by the OECD (1998). Shulus (1996) also broadly agrees with this categorisation: he introduces one more category that of the 'industrial generals'. However, Ageev et al. (1995), who study Russian entrepreneurship more or less at the same time with the Kuznetsova, the OECD and Shulus, offer an alternative categorisation that places much less emphasis on the 'intra-nomenclatura' divides. Thus, the 'Old Guard' comprises all those officials of state enterprises or of the socialist political infrastructure. Ageev et al. (1995) use the term 'new wave' entrepreneurs in a broader sense than other scholars in the field, including all those who search for innovations, and reflect the new economic thinking. Another grouping in this typology includes the 'unwilling entrepreneurs', i.e. those who are forced to take initiatives due to unemployment. The last cluster comprises foreign entrepreneurs - including returnees of the Russian Diaspora. In a very recent contribution to the debate Radaev (2001) focuses upon the nonnomenclatura entrepreneurs in Russia. He identifies three principal groups: those intermediaries 'servicing' large businesses, independent businesses producing for local markets, and individuals who start businesses without establishing their operational legality - such as shuttle traders. Smallbone and Welter (2001), drawing from the experience of the Ukraine, attempt a synthesis rather than develop a new typology. In doing so, they identify three groupings: the selfemployed and part-time business people, 'new generation' entrepreneurs and the nomenclatura.

Research on urban entrepreneurship in Russia and the Ukraine has progressed significantly during the past ten years or so. We now possess an understanding of the basic demographic features of practicing entrepreneurs, and of the main clusters of entrepreneurial behaviour. Although there appears to be little change in the attributes of the 'typical' entrepreneurial agent, it is apparent that in the 'hot-spots' of economic activity, in many cases the capital cities, there is a broadening of the types of individual involved in entrepreneurial pursuits. Apart from the nomenclatura and the directors of the socialist era, a number of other groups of willing and unwilling economic actors are involved in entrepreneurial pursuits. All of these entrepreneurial groupings rely less, than the nomenclatura, on remnants of the old institutional setting. At the same time, some of these entrepreneurial groupings are becoming increasingly influential - not necessarily numerically but through their ability to leverage resources. For example, 'new wave' entrepreneurs appear to be increasingly influential in determining the direction of institutional change in Russia and the Ukraine. The combined effect of limited reliance upon the old and the ability to influence change, means an accelerated (though obviously not uniform) pace of institutional change in urban centres. This leads to the development of an argument that: increased diversity among the population of entrepreneurs, and particularly the emergence of powerful new actors, augers well for the pace and direction of institutional change. 
Table 1. Entrepreneurial groupings and their characteristics in urban Russia and Ukraine

\begin{tabular}{|c|c|c|c|c|}
\hline Grouping & $\begin{array}{l}\text { Characteristics of } \\
\text { the entrepreneur }\end{array}$ & Main sector & Significance & Source \\
\hline $\begin{array}{l}\text { Directors of the } \\
\text { Socialist era }\end{array}$ & $\begin{array}{l}\text { Mainly males, } \\
\text { higher technical } \\
\text { education, have } \\
\text { risen from low level } \\
\text { duties to ma- } \\
\text { nagerial roles in the } \\
\text { old regime }\end{array}$ & $\begin{array}{l}\text { Large industrial } \\
\text { enterprises of } \\
\text { the Socialist era }\end{array}$ & $\begin{array}{l}\text { Important both } \\
\text { in rela-tive } \\
\text { and ab-solute } \\
\text { terms }\end{array}$ & $\begin{array}{l}\text { Gimpelson/Schultz } \\
1994 \\
\text { Ageev et al. } 1995 \\
\text { Khotin } 1996 \\
\text { Shulus } 1996 \\
\text { Kukolev } 1997 \\
\text { Kuznetsova } 1999\end{array}$ \\
\hline $\begin{array}{l}\text { Nomenclatura } \\
\text { entrepreneurs }\end{array}$ & $\begin{array}{l}\text { Mainly males, } \\
\text { higher education, } \\
\text { and experience of } \\
\text { working in political } \\
\text { structures }\end{array}$ & $\begin{array}{l}\text { Joint Ventures } \\
\text { with foreign } \\
\text { investors, } \\
\text { banking and } \\
\text { other large-scale } \\
\text { service ventures }\end{array}$ & $\begin{array}{l}\text { Important in } \\
\text { relative but } \\
\text { not in absolute } \\
\text { terms }\end{array}$ & $\begin{array}{l}\text { Ageev et al. } 1995 \\
\text { Kryshtalovskaya/White } \\
1996 \\
\text { Khotin } 1996 \\
\text { Hughes } 1997 \\
\text { Kukolev } 1997 \\
\text { Coulloudon } 2000\end{array}$ \\
\hline $\begin{array}{l}\text { Enterprising } \\
\text { Scientists }\end{array}$ & $\begin{array}{l}\text { Mainly male, many } \\
\text { have PhDs, have } \\
\text { experience of } \\
\text { working in Uni- } \\
\text { versities and Re- } \\
\text { search Institutes } \\
\end{array}$ & $\begin{array}{l}\text { ICT and other } \\
\text { high-tech } \\
\text { industries }\end{array}$ & $\begin{array}{l}\text { Modestly } \\
\text { important in } \\
\text { relative and } \\
\text { absolute terms }\end{array}$ & $\begin{array}{l}\text { Gimpelson/Schultz } \\
1994 \\
\text { Ageev et al. } 1995 \\
\text { Bruton/Rubanik } 1997 \\
\text { Kukolev } 1997 \\
\text { Kuznetsova } 1999\end{array}$ \\
\hline $\begin{array}{l}\text { Informal } \\
\text { entrepreneurs }\end{array}$ & $\begin{array}{l}\text { Relatively poorly } \\
\text { educated }\end{array}$ & $\begin{array}{l}\text { From shadow to } \\
\text { outright criminal } \\
\text { activities }\end{array}$ & $\begin{array}{l}\text { Important both } \\
\text { in re-lative } \\
\text { and ab-solute } \\
\text { terms }\end{array}$ & $\begin{array}{l}\text { Ageev et al. } 1995 \\
\text { Khotin } 1996 \\
\text { Shulus } 1996 \\
\text { Frisby } 1998 \\
\text { Volkov } 1998 \\
\text { Kuznetsova } 1999 \\
\text { Volkov } 2000 \\
\end{array}$ \\
\hline $\begin{array}{l}\text { Petty } \\
\text { entrepreneurs }\end{array}$ & $\begin{array}{l}\text { Often female, not } \\
\text { much else is known }\end{array}$ & $\begin{array}{l}\text { Petty trade and } \\
\text { service }\end{array}$ & $\begin{array}{l}\text { Information } \\
\text { not available }\end{array}$ & McMyllor et al. 2000 \\
\hline
\end{tabular}

\section{Methods and analysis}

The paper draws heavily upon the growing body of literature on entrepreneurship. Conceptually, it is influenced by the realisation among scholars in the field that entrepreneurs are not a homogeneous grouping, and may differ significantly from each other (Gartner 1985; Ucbasaran et al. 2002; Kalantaridis 2004). Within this context, we recognise the potential usefulness of typologies, that have been developed both in advanced market economies (Dunkelberg/Cooper 1982; Smith/Milner 1983; Gartner 1985; Davidsson 1988; Lafuente/Salas 1989; Robbie/Wright 1996) as well as post-socialist settings (Ageev et al. 1995; Shulus 1996; Kuznetsova 1999; Smallbone/Welter, 2001). 
The empirical part of the paper draws primarily upon the results of two surveys conducted in 2001. The first focused on the population at large and the criteria used in the stratification of the sample included age and gender. For the purpose of the survey a structured questionnaire was used, including sections on the personal details of the respondent, educational and work experience, current employment status, and general perceptions of entrepreneurship. In order to overcome the villagers' reluctance to participate in the survey the instrument was delivered on a face-to-face basis. Interviewers stressed the academic nature of the research and provided evidence of their credentials. Some 300 questionnaires were completed in the rural areas of each of the three regions (total 900). The second survey comprises of a stratified random sample of entrepreneurs in the same locales. During the earlier stages of the research the intention was to stratify the sample using criteria such as the number of years since the formation of the venture, the gender and the socio-economic grouping of the entrepreneur. However, the small number of practising entrepreneurs in the countryside of all three regions meant that more or less everyone who fell within the boundaries of our working definition, and were willing to participate in the study, was interviewed. A semi-structured schedule was developed for the purposes of the survey. Existing networks of contact and snowballing techniques were used in order to engage entrepreneurs who operated in the twilight world of semi-illegality. Again the academic nature of the research and the credentials of the interviewers assisted in this process. Some 100 interviews with entrepreneurs were conducted in each of the regions (total 300). In order to explore the distinctiveness (or not, as the case may be) of entrepreneurship in rural areas we attempt to make comparisons, with the body of literature derived from urban locations in Russia and the Ukraine. In doing so, we place particular emphasis upon the exploration of the methods used in different studies and potential implications upon the comparability of findings. Therefore, any comparisons are undertaken with extreme caution.

In analysing our data, and exploring the entrepreneurial potential of individuals we set out to develop a typology of rural entrepreneurs. A number of classification dimensions are used in previous studies - namely, goals, background and management style - as well as a combination of these (Dunkelberg/Cooper 1982; Smith/Milner 1983; Gartner 1985; Davidsson 1988; Lafuente/Salas 1989; Robbie/Wright 1996). However, these approaches have been much less influential in post-socialist settings (as discussed in the Section above). Within this context, the developmental impact (both in economic and structural terms) of entrepreneurs is the most commonly used criterion. This is influenced by the growing influence of Scase's distinction between entrepreneurs (economically significant) and proprietors (economically unimportant) and the ensuing scholarly debate (Smallbone/Welter 2004). Therefore, we deploy a similar criterion in our work. 
In operationalising the selection criterion each case study area is examined separately. Each entrepreneur is placed in the appropriate cluster using qualitative and quantitative information from the interview schedules rather than from a statistical technique, such as cluster analysis. The main reason behind this decision is the difficulty in 'translating' and codifying qualitative data. Our decisions, on a case by case base are based on the the findings of previous research, both in the western literature as well as the growing number of studies in post-socialist areas (discussed in considerable detail above), as well as our expectation of causes of potential diversity in rural areas (such as the importance of agriculture). Variables used in the development of the clusters include: information on the human capital held by the entrepreneur (including issues such as education, and employment and social status of the entrepreneur during the socialist era), the size of the business, the sector within which it operates (exploring the importance of petty trade and agriculture) as well as the gender of the entrepreneur. Thus it comes as no surprise that there are certain similarities (incidence of the 'old soviet director' type) as well as disparities in the emerging groupings that reflect the differences, at least in part, of the local socioeconomic milieu.

\section{The local context}

There are considerable differences between the three case study areas under investigation. As can be seen from Table 2, Transcarpathia is by far the smallest of the three localities: occupying less than one fourteenth of the land mass of the Novosibirsk region, and less than a third of the population of the Republic of Bashkortostan. Moreover, Transcarpathia also lacks a sizeable urban conurbation: Uzhgorod, has just 125,000 inhabitants in comparison to 1.1 million for Ufa, the regional capital of Bashkortostan, and 1.5 million for Novosibirsk city. This is combined with profound differences in the settlement structure of the countryside. On the one side, rural areas of the Novosibirsk region possess a small number of relatively remote settlements, whilst, on the other, rural Transcarpathia is characterised by high density of settlements. As far as location and accessibility is concerned, Table 2 and Figure 1 suggest that Transcarpathia is best placed, among the study areas examined, to take advantage of the opportunities emanating from the Western European markets. This is combined with a distinct historical heritage (only became part of the Soviet Union after the end of WW II) that gives Trascarpathia a more central European orientation. The Republic of Bashkortostan occupies a position in the semi-periphery of the Russian Federation, whilst Novosibirsk is the most geographically remote region, in terms of distance from the main markets of Russia.

Local development in the three areas under consideration is also influenced, at least in part, by the configuration of the terrain and the prevailing climatic 
conditions. Transcarpathia constitutes a predominantly mountainous locale. This is combined with poor resource endowments that offer precious few opportunities for economic growth in the countryside.

Table 2. An overview of the study areas (2000)

\begin{tabular}{|l|c|c|c|}
\hline & Transcarpathia & $\begin{array}{l}\text { Republic of Bash- } \\
\text { kortostan }\end{array}$ & Novosibirsk Region \\
\hline Area & 12,800 & 143,600 & 178,200 \\
\hline Population & $1,3000,000$ & $4,100,000$ & $2,700,000$ \\
\hline $\begin{array}{l}\text { Population density } \\
\text { (per square } \\
\text { kilometre) }\end{array}$ & 101.6 & 28.2 & 15 \\
\hline $\begin{array}{l}\text { Main city } \\
\text { (population) }\end{array}$ & Uzhgorod (125,000) & Ufa (1,100,000) & $\begin{array}{l}\text { Novosibirsk } \\
(1,500,000)\end{array}$ \\
\hline $\begin{array}{l}\text { Distance from capital } \\
\text { (in kilometres) }\end{array}$ & 750 & 1,500 & 3,200 \\
\hline $\begin{array}{l}\text { Agriculture as a } \\
\text { percentage of GDP }\end{array}$ & 33.4 & 11 & 10 \\
\hline $\begin{array}{l}\text { Subsistence } \\
\text { agriculture, as a per- } \\
\text { centage of land-mass }\end{array}$ & 50 & 3 & 5 \\
\hline $\begin{array}{l}\text { Private commercial } \\
\text { agriculture, as a } \\
\text { percentage of land- } \\
\text { mass }\end{array}$ & 3 & 15 & \\
\hline $\begin{array}{l}\text { Reformed agrarian } \\
\text { structures, as a } \\
\text { percentage of land- } \\
\text { mass }\end{array}$ & 47 & & \\
\hline
\end{tabular}

Source: Kalugina et al. 2001; Makhmutov 2002; Pityulich et al. 2001

As a consequence, rural areas in Trascarpathia are dominated by traditional agricultural pursuits, and to a lesser degree forestry. This is in sharp contrast, with the experience of the other two areas under investigation. The Republic of Bashkortostan is a relatively resource prosperous setting, which however, is confronted with relatively more hostile climatic conditions than Transcarpathia. Indeed, plains dominate the Western parts of the Republic, whilst the Urals occupy the East. More importantly however, the Republic possesses considerable oil and mineral resources that enable the development of very large,urban-based enterprises in the petrochemical industry (Makhmutov 2002). The Novosibirsk region is characterised by the predominance of plains but also by very hostile climatic conditions. This makes essential the provision of considerable social infrastructure for small rural communities, and influences economic development in the countryside. Thus, it comes as no surprise that a very small number - just 585 - of collectives or former state farms occupy the vast majority of the total farmland. 
The defining characteristics of the rural areas under investigation influence in part the views of the population regarding new entrepreneurial ventures. There is considerable evidence in the literature that negative views of entrepreneurship in the Russian and Ukrainian countryside predate socialism (Gerschenkron 1954). These views, re-enforced during the socialist era, are often linked closely withthe process of social reproduction. This is particularly the case for hostile (climatic) areas of the Russian Federation, where collective or state-owned organisations are responsible for maintaining large segments of the infrastructure (from keeping roads open during the winter to running local schools and nurseries). Thus, negative social views of the local population may act as a significant obstacle in the emergence of new, locally initiated entrepreneurial ventures in rural areas especially in the Republic of Baskhortostan and the Novosibirsk regions.

A key influence in the realisation of the entrepreneurial propensity of segments of the population is the state of reform and the evolution of institutions that underpin market transactions. In all three cases this can be best described as a hybrid between the old and the new. During the last fifteen years, a number of institutional reforms, invariably aiming to replicate institutions that have evolved in developed market economies over a period of at least two centuries, were introduced, ignoring the existing institutional arrangements and trying to write a new history as if on a blank slate. The emerging institutions are influenced in part by the pace and direction of reform, and co-evolve with the old institutions in a process of re-functionality and hybridisation. However, the specificities and pace of this process differ significantly between the three case study areas. Transformation 'in the Ukraine is characterised by the fact that it started later than in most European post-socialist countries and the process of marketisation has proceeded more slowly and haltingly having been interrupted by periods of increased administrative control' (Van Zon 1998:610). Moreover, the pace of privatisation varies significantly from region to region, however, Transcarpathia appears to be considerably ahead than the national average (TESF 2001). By 2000, what is often referred to as the first generation reforms, with the establishment of relatively well-defined private property rights, the introduction and stabilisation of a new currency, liberalisation of prices and trade, and privatisation of the bulk of the small-scale sector was complete (Ernst \& Young 2001). In the Republic of Bashkortostan the pace of reform is slow and only partial. This is manifested in the delay in liberalising the market for agricultural land and the decision to perpetuate large-scale collectives, and transform them into 'new' co-operatives. This was especially the case during the early stages of the reform (1991-1996) (Makhmutov 2002). During the following five years 62 different legislative documents were introduced, regarding small businesses, free enterprise and peasant property, creating an image of tightly controlled move towards a market economy. Policy-makers in the Novosibirsk region enjoy a much lower degree of autonomy than their 
counterparts in the Republic of Bashkortostan and Transcarpathia. As a result, the introduction of reforms and the development of institutions that underpin market transactions in the region broadly reflect the national trends. Thus, at the time of the survey, legal reforms regarding markets and the introduction of welldefined private property rights had advanced considerably (EBRD 2001). At the same time, macro-economic indicators had improved significantly, offering grounds for modest optimism regarding economic growth. However, the economy remained heavily reliant upon a relatively small number of very large business, and the small business sector failed to make a significant impact either in terms of employment or income.

\section{The characteristics of rural entrepreneurs}

Rural entrepreneurs in all three case study areas, like their urban-based are predominantly males (Table 3 ). However, the incidence of female entrepreneurs is well above that reported in the body of existing literature that draws primarily from urban locations. This could be interpreted either as evidence of moderate variation in the gender division of entrepreneurship in the countryside, or as a continuation of a trend identified by OECD (1998) towards greater involvement of females in the process of business enterprise. Another, and more plausible in our view, explanation for the urban-rural differential in the gender division of entrepreneurs maybe differences in sample selection.

Rural entrepreneurs like their urban-based counterparts are better-educated individuals than the population at large. Thus, five times as many rural entrepreneurs as rural inhabitants (not engaged in the process of business enterprise) posses a university degree or post-graduate qualification in the Novosibirsk region. Significant disparities in educational achievement also exist in the rural areas of the other two regions. In the case of the Republic of Bashkortostan nearly 2.6 times as many rural entrepreneurs as the population are educated to degree level or above, a figure moderately above that for Transcarpathia (1.9). Overall, however, the incidence of higher education among rural entrepreneurs - in absolute figures, ranging from $38 \%$ in Transcarpathia to $55 \%$ in the Republic of Bashkortostan - appears to be lower than that reported in earlier studies drawing upon the experience of urban areas (where higher education is reported by $80 \%$ of entrepreneurs).

The age profile of rural entrepreneurs differs somewhat between the three rural locales under investigation. Transcarpathia demonstrates a greater incidence of younger individuals than Novosibirsk (see Table 4). Overall, though rural entrepreneurs appear to be clustered in the two middle age groups. This differs somewhat from the experience of urban areas - as identified in the literature. In urban areas there is a greater incidence of young people, i.e. those below the age of 25 , than in the countryside of Russia and the Ukraine. 
Table 3. The characteristics of rural entrepreneurs in comparison to the rest of the population in the three study regions (in percentages)

\begin{tabular}{|c|c|c|c|c|c|c|}
\hline & \multicolumn{2}{|c|}{ Transcarparthia } & \multicolumn{2}{|c|}{ Republic of Bashkortostan } & \multicolumn{2}{|c|}{ Novosibirsk } \\
\hline & Entrepr. & Population & Entrepr. & Population & Entrepr. & Population \\
\hline \multicolumn{7}{|l|}{ Gender } \\
\hline Males & 67 & 51 & 74 & 58 & 63 & 48 \\
\hline Females & 33 & 49 & 26 & 42 & 37 & 52 \\
\hline \multicolumn{7}{|l|}{ Education } \\
\hline $\begin{array}{l}\text { University } \\
\text { education }\end{array}$ & 38 & 20 & 55 & 21 & 42 & 8 \\
\hline \multicolumn{7}{|l|}{ Age } \\
\hline $\begin{array}{l}18-25 \text { years } \\
\text { old }\end{array}$ & 6 & 14 & 4 & 18 & 4 & 11 \\
\hline $\begin{array}{l}26-40 \text { years } \\
\text { old }\end{array}$ & 47 & 41 & 48 & 30 & 39 & 42 \\
\hline $\begin{array}{l}41-60 \text { years } \\
\text { old }\end{array}$ & 46 & 41 & 47 & 30 & 49 & 46 \\
\hline $\begin{array}{l}61+\text { years } \\
\text { old }\end{array}$ & 0 & 4 & 1 & 23 & 8 & 1 \\
\hline
\end{tabular}

Source: Population \& entrepreneurs' surveys

\section{Entrepreneurial groupings}

For the purposes of our investigation entrepreneurial groupings are developed for each of the three study areas (Table 4). Transcarpathia constitutes an environment where traditional rural resources (such as agricultural land) are in short supply - at least in relation to the other two regions. Geographical location near the prosperous markets of Central Europe, that offers the scope for crossborder exchange, constitutes a source of local competitive advantage. Thus, four main groupings are identified: the old soviet directors, petty traders, petty entrepreneurs in other industries, and new capitalist entrepreneurs (Table 4). The first cluster of rural entrepreneurs are involved in larger organisations, established (on average) 3.1 years prior to the conduct of the survey (see Table 4). In terms of industrial sector, entrepreneurial directors are concentrated in trade (44\%), and agriculture (18\%). This grouping comprises predominantly male individuals who were born and spent the best part of their working lives under the socialist regime. More than $40 \%$ of those falling in this category also possess university degrees or above, with the remaining holding technical qualifications. More importantly, however, during the socialist era these individuals have risen to positions of power within State enterprises. Thus, at the start of the reform process they were well placed to tap into opportunities emanating from privatisation. Overall, entrepreneurial directors account for $17 \%$ of the interviewees in rural Transcarpathia.

The second cluster of rural entrepreneurs includes those individuals involved in petty trading activities (either cross-border or between the city and the village). None of them run large enterprises (see Table 4), in fact, the overwhelming 
majority of entrepreneurs in this grouping employs one to five workers, some of whom may be members of the entrepreneurial family. The mean age of the firm was 3.5 years at the time of the survey. They tap into the multitude of opportunities generated by the destruction of the distribution channels of the socialist era, using very modest capital resources. Half of all individuals falling in this cluster are females, a figure well above that for rural Transcarpathia as a whole. They are invariably younger individuals than those falling in the other groupings. Thus, their experience of economic activity under socialism is limited - or in many cases non-existent. Half of them are educated to degree level or above (the highest percentage in this region), whilst $43 \%$ have only got a secondary education (also the highest figure in the region). Unlike the entrepreneurial directors, petty traders possess neither the experience nor the network of contacts that can enable them to benefit from early privatisation. Instead, for many of them, the disintegration of the old regime frustrated well laid out plans about the transition from higher education to secure salaried employment. Rural petty traders make up $14 \%$ of the sample in Transcarpathia.

Table 4. Entrepreneurial groupings and enterprise characteristics

\begin{tabular}{|c|c|c|c|}
\hline & $\begin{array}{l}\text { Main Sectors of } \\
\text { Activity (\%) }\end{array}$ & $\begin{array}{l}\text { Large Ventures* } \\
\text { (\%) }\end{array}$ & Mean Age of Firms \\
\hline \multicolumn{4}{|l|}{ Transcarpathia } \\
\hline $\begin{array}{l}\text { Old Soviet } \\
\text { Directors }\end{array}$ & $\begin{array}{l}\text { Trade }(45.5 \%) \\
\text { Agriculture }(18 \%)\end{array}$ & $12 \%$ & 3.1 \\
\hline Petty Traders & Trade $(100 \%)$ & 0 & 3.5 \\
\hline $\begin{array}{l}\text { Petty entrepreneurs } \\
\text { in other industries }\end{array}$ & $\begin{array}{l}\text { Agriculture (44\%) } \\
\text { Services }(32 \%)\end{array}$ & 0 & 2.2 \\
\hline $\begin{array}{l}\text { Capitalist } \\
\text { entrepreneurs }\end{array}$ & $\begin{array}{l}\text { Trade }(44 \%) \\
\text { Construction }(22 \%)\end{array}$ & $9 \%$ & 3.8 \\
\hline \multicolumn{4}{|l|}{ Bashkortostan } \\
\hline $\begin{array}{l}\text { Old Soviet } \\
\text { Directors }\end{array}$ & $\begin{array}{l}\text { Agriculture }(31 \%) \\
\text { Construction }(20 \%) \\
\text { Manufacture }(13 \%)\end{array}$ & $12 \%$ & 4.2 \\
\hline Petty Entrepreneurs & $\begin{array}{l}\text { Construction }(30 \%) \\
\text { Finance }(25 \%)\end{array}$ & 0 & 3.7 \\
\hline $\begin{array}{l}\text { Capitalist } \\
\text { Entrepreneurs }\end{array}$ & $\begin{array}{l}\text { Trade }(33 \%) \\
\text { Manufacture (17\%) }\end{array}$ & $66.7 \%$ & 4 \\
\hline \multicolumn{4}{|l|}{ Novosibirsk } \\
\hline $\begin{array}{l}\text { Old Soviet } \\
\text { Directors }\end{array}$ & Agriculture (61\%) & $16 \%$ & 8 \\
\hline $\begin{array}{l}\text { Non-agricultural } \\
\text { entrepreneurs }\end{array}$ & $\begin{array}{l}\text { Trade }(66 \%) \\
\text { Service }(21 \%)\end{array}$ & $0 \%$ & 4.1 \\
\hline $\begin{array}{l}\text { Capitalist } \\
\text { entrepreneurs in } \\
\text { agriculture }\end{array}$ & Agriculture (100\%) & $4 \%$ & 8.8 \\
\hline
\end{tabular}

* Denotes enterprises employing more than thirty persons 
Petty entrepreneurs engaged in activities other than trade make-up the third grouping. None of them run large businesses (see Table 4), indeed, the overwhelming majority of the enterprises created by these entrepreneurs employ up to five persons. The enterprises are younger than those of the previous two groupings and are involved in agriculture (44\%) and service provision (32\%). Most are males, and most of them are relatively younger individuals. Thus, they possess some experience of economic relationships of the previous regime. University education among those falling in the third grouping is lower than that for both the old soviet directors and petty traders. However, nearly half of them possess some technical qualifications that equip them with practical knowledge and skills about production processes. Petty entrepreneurs engaged in activities other than trade comprise more than half $(58 \%)$ the sample in rural Transcarpathia.

The fourth cluster of rural entrepreneurs includes those individuals that appear to possess the greater developmental potential. These are new capitalist entrepreneurs who have been able to expand successfully, and currently offer wage employment to a number of persons. Thus, one in ten run larger enterprises (see Table 4). The mean age of the firm was 3.8 years - the highest among all four groups in Transcarpathia. The enterprises created by these individuals are engaged in trade (44\%), and service provision (22\%). Those falling in this category are predominantly males. Moreover, new capitalist entrepreneurs are relatively older individuals - especially in relation to petty entrepreneurs both in trade and other activities. Thus, they have lived and worked for the best part of their life under the 'old' economic regime. However, their level of educational attainment is well below that of all the other three groupings. 'New' capitalist entrepreneurs account for $11 \%$ of the sample in rural Transcarpathia.

In the Republic of Bashkortostan three main groupings are identified: the old soviet directors, petty entrepreneurs, and capitalist entrepreneurs. Those falling in the first grouping run mainly larger enterprises, with one in ten employing more than thirty persons at the time of the survey. These are the longest established enterprises, with a mean age of 4.2. In terms of industrial sector they are primarily involved in agriculture (31\%), construction $(20 \%)$ and manufacturing (13\%). Most of them are males, however, rather unexpectedly, they are not older than their counterparts in the other two categories. Despite their age entrepreneurial directors themselves or members of their families were able to rise in positions of authority during the Socialist regime. This combined with widespread incidence of higher education qualifications, means that they are well placed to tap into opportunities arising from the process of reform. Old soviet directors are undoubtedly the prevailing form of rural entrepreneurship: 74 out of 100 interviewees fall in this grouping. This is in sharp contrast with 
the experience of Transcarpathia where this type of rural entrepreneurship accounts only for a minority of the total.

The second grouping comprises of those individuals who start micro-level enterprises that employ predominantly family labour. Indeed, none of the petty entrepreneurs engages more than thirty people (see Table 4), and run invariably younger enterprises, engaged in construction (30\%), and finance (25\%). Females dominate this grouping. Their age distribution does not differ significantly from that of rural entrepreneurs as a whole, and are well educated, though probably less so than the old soviet directors. Petty entrepreneurs are only of modest importance in the countryside of the Republic of Bashkortostan, accounting for one in five of the total.

The third grouping comprises of those capitalist entrepreneurs, who are able to expand their ventures considerably and employ a number of wage employees. This is reflected at the level of total employment provided by those individuals, in all cases above ten, whilst in many instances more than thirty (see Table 4). They engage in trade (33\%) and manufacturing (17\%). This grouping is madeup exclusively by males. They are relatively older individuals - two thirds are 40 years old or over. Half of the capitalist entrepreneurs are educated to degree level or above (the highest in the rural areas of the Republic of Bashkortostan). Overall, there are only six capitalist entrepreneurs in the Republic of Bashkortostan.

Entrepreneurs in the rural areas of the Novosibirsk region are grouped into three main clusters. The first grouping comprises of the old soviet directors, many of whom run enterprises that employ more than thirty persons, in agriculture $(61 \%)$ - as shown in Table 4. Four fifths of those falling in this grouping are males. Entrepreneurial directors are older and very well educated. Entrepreneurial directors in the rural areas of the Novosibirsk region most closely resemble the characteristics commonly associated with this grouping in the existing literature. However, their incidence is less than half (34\%) that reported in the Republic of Bashkortostan.

'Petty' entrepreneurs engaged in activities outside agriculture bear some resemblance with the petty traders of Transcarpathia, and the petty entrepreneurs of the Republic of Bashkortostan. Nearly all employ one to five persons. The overwhelming majority is involved in trading activities, with others concentrated in the repair and service of machinery. Those falling in this grouping are predominantly females and are younger than the average for the region. However, unlike both the old soviet leaders in the rural areas of Novosibirsk and their counterparts in the other two regions, non-agricultural entrepreneurs are very poorly educated. They make up a significant percentage $(39 \%)$ of the sample in rural parts of the Novosibirsk region. 
The last entrepreneurial grouping comprises of those individuals who became involved in the process of business enterprise during the past ten years or so, and set-out to exploit the significant agricultural resources of the region. All of them employ a number of wage employees, whilst a minority has expanded their ventures considerably and employ more than thirty persons (Table 4). Nearly all of those falling in this category are males, and nearly two thirds are forty years old or more. In these two respects they bear some similarities with the old soviet leaders in the region. However, unlike the entrepreneurial directors, new agricultural entrepreneurs are not as well educated. There appear to be two processes of emergence among capitalist entrepreneurs in agriculture. Some of them are petty entrepreneurs who were successful in accumulating capital from petty trade and subsequently invest it in agriculture. A smaller number appear to be individuals who have succeeded in an urban setting and now set out to exploit rural resources. Capitalist entrepreneurs in agriculture account for $27 \%$ of respondents in the rural areas of Novosibirsk.

Overall, there are significant differences in the entrepreneurial groupings reported in rural areas, in comparison to those identified in the exclusively urban-based literature. Nomenclatura entrepreneurs are absent from the rural areas under investigation. This can be explained on account of differential opportunities open to members of the nomenclatura: with urban localities, and the national and regional capitals in particular, offering greater scope for their activities. 'New' capitalist entrepreneurs in rural areas also differ profoundly from the urban-based new generation business people. Literature, from the main conurbations of Russia and the Ukraine, portrays them as young and wellqualified individuals who perceive entrepreneurship as an outlet for their creative capabilities. In all three case study regions, those individuals falling in the 'third' grouping are older individuals - with an age structure similar to that of the old soviet directors. Moreover, 'new' capitalist entrepreneurs are not as well educated as those in other groupings. In fact, new capitalist entrepreneurs in the countryside often appear to come from the ranks of early petty entrepreneurs of the early post-socialist era, who survived and expanded over the past decade or so. Lastly, in the countryside, especially in the Ukraine, we have identified a much greater incidence of entrepreneurs that bear greater similarities with the unregistered individuals who provided services in the Breznev era (Kuznetsova 1999) rather than any contemporary archetypes. Many entrepreneurs falling in this category are younger females, who are driven by push factors. As a result, many rural entrepreneurs are engaged in petty activities, predominantly in trade or service provision, defined ease of entry and exit conditions.

However, there are also differences in the emerging entrepreneurial groupings in the three rural areas under investigation. The first disparity is linked with differences in the numerical importance of different groupings in each rural area. Old Soviet directors account for nearly three quarters of all rural entrepreneurs 
in the Republic of Bashkortostan, in sharp contrast to Trascarpathia - where they make-up less than one fifth of the total. The later rural landscape is dominated by petty entrepreneurs, in trade and beyond. This grouping is of much lesser importance in the Republic of Bahksortostan. Lastly, capitalist entrepreneurs are more important in rural areas of the Novosibirsk region, around one in four of the total. This figure is more than four times that reported in the Republic of Bashkortostan. However, there are also qualitative differences between similar entrepreneurial groupings, indicative of diverse processes at work in the three rural areas examined here. More specifically, the age profile of the entrepreneurs indicates that, at the time of the survey, a generational shift was achieved by old soviet directors in the Republic of Bashkortostan. This means that control was passed to relatively younger directors of the old era, or offspring of those in control during the 1980s. This process is not apparent in the two other case study areas. Moreover, the levels of educational attainment vary significantly between rural petty traders in Transcarpathia and petty entrepreneurs in Novosibirsk region (half of the former are educated to degree level, a figure nearly four times than the latter). In Transcarpathia, petty trade appears to offer an opportunity for advancement. This appears to be in contrast to the case of Novosibirsk, where petty entrepreneurship is viewed relatively negatively by local communities, and thus becomes the realm of poorly educated, often in-migrant, women.

\section{Entrepreneurs and institutional change}

The evidence presented in this paper illustrates a significant diversity of context, firstly between urban and rural areas, and secondly between the three rural areas under investigation. Within this setting of diversity, the role of entrepreneurial individuals as agents of institutional change may differ significantly. This is partly on account of their ability to influence, and partly due to their willingness to pursue change. In this Section we set out to interpret the data presented earlier in the paper regarding entrepreneurs as agents of institutional change.

It is fairly apparent from the accumulated literature that entrepreneurial individuals in urban areas appear to be well placed to influence institutional change. One reason behind this conclusion is the growing number of entrepreneurs in the more opportune settings offered by cities. Another, and probably more important, reason involves the emergence of relatively powerful entrepreneurial groupings. Both nomenclatura entrepreneurs and enterprising scientists (see Table 1) appear to possess power to influence the process of institutional change. Off course there may be significant diversity in the willingness of such individuals to influence change. Enterprising scientists are themselves the result of change in the institutional setting and may have a vested interested in advancing further change (Kuznetsova 1999). This stands in sharp contrast with the interests of the nomenclatura entrepreneurs, who rely heavily 
upon continuity (Kryshtalovskaya/White 1996). Their oft competing actions are one of the influences of institutional change in urban areas. However, in rural areas the picture is somewhat different. There the predominance of old soviet directors and the relative weakness of capitalist entrepreneurs, combined with the perpetuation of negative views regarding entrepreneurs among the population at large does not auger well for change. However, there are also disparities between the three case study areas under investigation.

In Transcarpathia, the influence of old soviet directors is diminished significantly: partly because soviet structures were introduced late (1946), and partly due to that fact that they never underpinned the local social infrastructure. This is combined with the emergence of a myriad of petty entrepreneurial ventures and a small number of capitalist entrepreneurs. They enact or 'translate' change that emanates from the core (national or regional). This makes the region (unlike Ukraine) appear as relatively advanced, in comparison to the other two (Russian) case study areas under investigation. This is not the case in the Republic of Bashkortstan. There, the 'entrepreneurial landscape' appears to have evolved only marginally from that of the socialist era, when the directors of state or collective enterprises dominated economic activity. It is the very same families and in many cases individuals who re-invent themselves in the postsocialist context. In this setting petty entrepreneurs are forced into a symbiotic relationship (in the sense of engaging in activities not performed by, or at the margins of reformed collective or state enterprises) with the old soviet directors, whilst capitalist entrepreneurship is only of marginal importance. Thus, it comes as no surprise that in rural areas of the Republic of Bashkortstan the pace of change is particularly slow. Whilst, this does not auger well for the emergence of a new regime, it also means that this locale never reached the depth of economic decline reported elsewhere in Russia (Makhmutov et al. 2002). The situation is somewhat different in rural areas of the Novosibirsk region - where there is a gradual evolution of petty entrepreneurs into capitalist entrepreneurs who acquire large tracks of agricultural land. They appear to be the sole sizeable grouping - throughout our three case study areas - that actually 'challenges' old soviet directors for resources (land). In their attempt to displace the existing order, they are confronted with considerable local reaction as they are widely viewed as a threat to the local social infrastructure. Within this context, it is the old soviet directors that are viewed as welfare capitalists operating a paternalistic regime in small communities. They maintain elements of the social infrastructure that are essential for survival in hostile climatic conditions.

\section{Conclusions}

This paper argues that the defining characteristics of rurality influence significantly the emerging entrepreneurial groupings (especially when compared with urban areas). Their relative isolation from national and international 
circuits of capital and opportunities, as well as political and social processes, which is largely due to their economically marginal position, prevents the emergence of large numbers of new capitalist entrepreneurs - as is the case in urban locales. Instead, the evidence presented here suggests that the overwhelming majority of entrepreneurial individuals in the countryside fall in one of two main groupings: those in position of authority during the Soviet era and those - predominantly women - operating at the margins. As far as the former grouping is concerned, they are able to reinforce their early advantage, by exploiting opportunities, which in turn restrict the scope for the emergence of entrepreneurial groupings that are increasingly common in the main urban conurbations. However, their role on the countryside appears to be equivocal. In some instances, they may be using their position of power in order to monopolise access to valuable resources and accumulate personal wealth, whilst in others they can be seen as 'welfare capitalists' operating within a paternalist regime of accumulation with welfare commitments to local residents. As far as petty entrepreneurs are concerned, they are able to continue operating (often) at the margins, securing a living for themselves and their families, but remain unable to introduce change and challenge the position of the old Soviet directors. Together old Soviet directors and petty entrepreneurs make up between 74\%, in Novosibirsk region, and $95 \%$, in the Republic of Bashkortostan, of rural entrepreneurs - a figure well above that reported in urban areas. Urban-rural contrasts, should not conceal significant differences apparent between the three case study areas examined here. These disparities only reinforce the need for an increase in the emphasis (and the number of studies) conducted in the psot-socialist countryside.

Moreover, and rather perversely (in the context to the accumulated literature), the prospects of institutional change in the countryside rest heavily in the hands of petty entrepreneurs. Can those individuals - Scase's proprietors - who operate at the margins reinvent themselves as key agent's of change? The evidence presented here is inconclusive. In the main, petty entrepreneurs (either in trade or in other activities) are unable or unwilling to transform themselves into capitalist entrepreneurs. This could be explained on account of a number of factors at work. In the case of the Republic of Bashkortstan and the Novosibirsk region, this may be on account of the negative views of local communities combined with the still significant role of old soviet directors. In the case of Transcarpathia this may be explained by the combined effect of limited availability of capital and profoundly different turnaround times between trade (on the one side) and agriculture and manufacturing (on the other). Only in the case of the Novosibirsk region, there is a gradual evolution of a small number of petty entrepreneurs into capitalist entrepreneurs who acquire large tracks of agricultural land. They appear to be the only grouping - throughout our three case study areas - that actually 'challenges' old soviet directors for resources 
(land). To what extent will they be able to introduce change remains questionable.

Lastly, this paper suggests a significant shift in the direction of research on institutional change. We believe the singular emphasis placed upon the actions of the state and formal processes at work needs to be modified. The actions of other economic agents (including the entrepreneurs) may enable us to acquire a better understanding of institutional change. As shown in the case of rural areas of the Novosibirsk region the realities of change are complex. Whilst change may appear positive in the long-term, continuity is essential for survival in a hostile setting. A move beyond formality to informal institutional arrangements that enable the working of the evolving hybrid post-socialist regimes may further enrich our knowledge. More importantly however, this shift will be of particular importance in terms of policy. The recognition of the importance of other agents and informal arrangements may enable the adoption of a more pragmatic view of how change can take place.

\section{References}

Acs, Z./Karlsson, C. (2002): Introduction to Institutions, Entrepreneurship and Firm Growth: From Sweden to the OECD, in: Small Business Economics, 19, 183-187.

Ageev, A. I./Gratchev, M. V./Hisrich, R. D. (1995): Entrepreneurship in the Soviet Union and Post-Socialist Russia, in: Small Business Economics, 7, 5, 365-376.

Allina-Pisano, J. (2004): Land Reform and the Social Origins of Private Farmers in Russia and Ukraine, in: Journal of Peasant Studies, 31, 3/4, 489-514.

Barkhatova, N./McMylor, P./Mellor, R. (2001): Family business in Russia: the path to middle class, in: British Journal of Sociology, 52, 2, 249-269.

Binks, M./Vale, P. (1991): Entrepreneurship and Economic Change. London: McGraw-Hill.

Brazeal, D. V./Herbert, T. T. (1999): The Genesis of Entrepreneurship, in: Entrepreneurship Theory and Practice, 23, 3, 29-45.

Bruton, G. D./Rubanik, Y. (1997): High Technology Entrepreneurship in Transititional Economies: The Russian Experience, in: Journal of High Technology Management Research, 8, 2, 213-224.

Cantillon, R. (1932): Essai sur la nature de commerce en general. London: Macmillan.

Choi, Y. B. (1993): Paradigms and Conventions Uncertainty, Decision-making and Entrepreneurship. Ann Arbor: University of Michigan Press.

Coulloudon, V. (2000): The Divided Russian Elite: How Russia's Transition Produced a Counter-Elite, in: Sperling, V. (ed.): In Building the Russian State: Institutional Crisis and the Quest for Democratic Governance, Boulder, Colorado: Westview Press, 6787. 
Davidsson, P. (1988): Type of man and type of company revisited: a confirmatort cluster analysis approach, in: Kirchoff, B.A./Long, W. A./McMullan, W. E./Vesper, K./Wetzel, W. Jr (eds): Frontiers of Entrepreneurship Research, Wellesley, MA: Babson College, 88-105.

Dunkelberg, W. C./Cooper, A. C. (1982): Entrepreneurial typologies: an empirical study, in: Vesper, K. A. (ed.): Frontiers of Entrepreneurship Research, Wellesley, MA: Babson College, 1-15.

Ekelund, R. B./Herbert, R. F. (1997): A History of Economic Theory and Method. New York: McGraw-Hill.

Ernst \& Young(2001): Ukraine: A Business and Investment Guide. Kiev.

Frisby, T. (1998): The Rise of Organised Crime in Russia: Its Roots and Social Significance, in: Europe-Asia Studies, 70, 1, 27-49.

Gartner, W. B. (1985): A Conceptual Framework for Describing the Phenomenon of New Venture Creation, in: Academy of Management Review, 10, 4, 696-706.

Gimpelson, V./Schultz, A. (1994): New Russian Entrepreneurship, in: Russian Social Science Review, 35, 3, 19-36.

Gerschenkron, A. (1954): Social attitudes, entrepreneruship and economic development, in: Explorations in Entrepreneurial History, VI, 1-19.

Green, R./David, J./Dent, M. (1996): The Russian entrepreneur: a study of psychological characteristics, in: International Journal of Entrepreneurial Behaviour \& Research, 2, $1,49-58$.

Hughes, J. (1997): Sub-National Elites and Post-Communist Transformation in Russia: A Reply to Kryshtanovskaya and White, in: Europe-Asia Studies, 49, 6, 49-58.

Johnson, S./McMillan, J./Woodruff, C. (2000): Entrepreneurs and the ordering of institutional reform Poland, Slovakia, Romania, Russia, and Ukraine compared, in: Economics of Transition, 8, 1, 1-36.

Kalantaridis, C. (2004): Understanding the Entrepreneur An Institutionalist Perspective. Aldershot: Ashagate.

Kalugina, Z. I./Arsentieva, N. M./Koshleva, O. P./Oleh, A. L./Fadeeva, O. P. (2001): Rural Entrepreneurship and Employment in Transition Economies The Case of the Novosibirsk Region, INTAS Project 99-00965.

Khotin, L. (1996): Old and New Entrepreneurs in Today's Russia, in: Problems of Post Communism, 43, 1, 49-57.

Klochko, Y./Issakova, N. (1996): Small business sector in Ukrainian transition economy: achievements to date, in: Entrepreneurship \& Regional Development, 8, 2, 127-140.

Kryshtanovskaya, O./White, S. (1996): From Soviet Nomenklatura to Russian Elite, in: Europe-Asia Studies, 48, 5, 711-734.

Kukolev, I. V. (1997): The Formation of the Business Elite, in: Russian Social Science Review, 38, 4, 62-83.

Kuznetsov, A./Kuznetsova, O. (2003): Institutions, Business and the State in Russia, in: Europe-Asia Studies, 55, 6, 907-922. 
Kuznetsova, N. (1999): Roots and Philosophy of Russian Entrepreneurship, in: Journal for East European Management Studies, 4, 1, 45-72.

Lafuente, A./Salas, V. (1989): Types of entrepreneurs and firms: the case of new Spanish firms, in: Strategic Management Journal, 10, 17-30.

Luthans, F./Staikovic, A. D./Ibrayeva, E. (2000): Environmental and psychological challenges facing entrepreneurial development in transitional economies, in: Journal of World Business, 35, 1, 95-110.

Mcmillan, J./Woodruff, C. (2002): The Central Role of Entrepreneurs in Transition Economies, in: Journal of Economic Perspectives, 16, 3, 153-170.

McMylor, P./Mellor, R./Barhkatova, N. (2000): Familialism, Friendship and the Small Firm in the New Russia, in: International Review of Sociology, 10, 1, 125-146.

Makhmutov, A. (2002): Final Report of the National Team of the Republic of Bashkortostan, INTAS Project 99-00965.

Martinelli, A. (1994): Entrepreneurship and Management, in: Smelser, N. J./Swedberg, R. (eds): The Handbook of Economic Sociology, Princeton: Princeton University Press, 476-503.

Obolonski, A. (1997): Post-soviet officialdom: a quasi-bureaucratic ruling class, in: Sociological Research, 36, 6, 65-82.

OECD (1998): Entrepreneurship and Small Business in the Russian Federation. Paris: OECD Publications.

Pityulich, M. I./Sochka, K./Zavadyak, R. (2001): Development of Entrepreneurship, Employment and Living Standards of Transcarpathian Rural Population, INTAS Project 99-00965.

Radaev, V. (1997): Practicing and Potential Entrepreneurs in Russia, in: International Journal of Sociology, 27, 3, 15-21.

Radaev, V. (2001): The Development of Small Entrepreneurship in Russia, WIDER Discussion Paper 2001/135.

Rehn, A./Taalas, S. (2004): Znakomstva I Scyazi (Acquaintances and connections) - Blat, The Soviet Union and mundane Entrepreneurship, in: Entrepreneurship and Regional Development, 16, 3, 235-250.

Roberts, K./Tholen, J.(1998): Young entrepreneurs in East-Central Europe and the former Soviet Union, in: IDS Bulletin, 29, 3, 59-64.

Robbie, K./Wright, M. (1996): Management Buy-ins: Active Investors and Corporate Restructuring. Manchester: Manchester University Press.

Say, J. B. (1830 original 1803): A Treatise on Political Economy. New York: Augustus M. Kelley.

Scase, R. (1997): The Role of Small Businesses in the Economic Transformation of Eastern Europe: Real but Relatively Unimportant, in: International Small Business Journal, 16, $1,13-21$.

Scase, R. (2003): Entrepreneurship and Proprietorship in Transition: Policy Implications for the SME Sector, in: McIntyre, R./Dallago, R (eds): Small and Medium Enterprises in Transition Economies, London: McMillan, 64-77. 
Schumpeter, J. A. (1934): History of Economic Analysis. London: Allen and Unwin.

Seckler, D. (1975): Thorstein Veblen and the Institutionalists: A Study in the Social Philosophy of Economics. London: Mcmillan.

Shulus, A. (1996): Entrepreneurship in the former Soviet Union and Russia (1985-1994), in: Klandt, H./Rosa, P./Scott, M. (eds): Educating Entrepreneurs in Modernising Economies, Aldershot: Avebury.

Smallbone, D./Welter, F. (2001): The Distinctiveness of Entrepreneurship in Transition Economies, in: Small Business Economics, 16, 249-262.

Smallbone, D./Welter, F. (2004): Conceptualising Entrepreneurship in a Transition Context, paper presented to Rent XVII.

Smith, N. R./Milner, J. R. (1983): Type of entrepreneur, type of firm, and managerial motivation: implications for organisational life cycle theory, in: Strategic Management Journal, 4, 325-340.

TESF (2001) Business Partner Transcarpathia, Uzhgorod: TESF.

Van Zon, H. (1998): The mismanaged integration of Zaporizhzhya with the world economy: implications for regional development in peripheral regions, in: Regional Studies, 32, 7, 607-618.

Ucbasaran, D./Westhead, P./Wright, M. (2002): The Focus of Entrepreneurial Research: Contextual and Process Issues. Institute for Enterprise and Innovation: University of Nottingham.

Veblen, T. B. (1914): The Instinct of Workmanship and the State of Industrial Arts. New York: Augustous Kelly.

Volkov, V. (1998): Who is Strong when the State is Weak? Violent Entrepreneurs in PostCommunist Russia, paper presented at the Conference 'Russia at the End of the Twentieth Century' Stanford University.

Wegren, S. K. (2004): From Communism to Capitalism? Russia's Agrarian Relations in the Twentieth Century and Beyond, in: Journal of Peasant Studies, 31, 3/4, 363-399. 